Jurnal Sewaka Bhakti Lembaga Penelitian dan Pengabdian Kepada Masyarakat Universitas Hindu Indonesia Denpasar Volume 2, Nomor 1 April 2019 ISSN: 2654-2935 (Online)

https://ejournal.unhi.ac.id/index.php/sewakabhakti pp. $73-81$

\title{
PEMANFAATAN KUNYIT MENJADI MINUMAN SERBUK INSTAN DI DESA PAKRAMAN PAU KECAMATAN BANJARANGKAN KLUNGKUNG
}

Putu Lakustini Cahyaningrum, Ida Bagus Putra Suta, Sang Ayu Made Yuliari Program Studi Kesehatan Ayurweda, Fakultas Kesehatan, Universitas Hindu Indonesia

\begin{abstract}
Pakraman Pau Village is one of the villages located in Banjarangkan District, Klungkung Regency, Bali Province. As one of the developing villages in Klungkung which is rich in herbal plants. Many herbal plants are planted on farms and in the homes of residents, especially turmeric. Utilization of turmeric has not been processed optimally, especially in the area of increasing health and added value in helping to improve the family economy. Previously, Pakraman Pau villagers used turmeric only as a kitchen spice and were used as a loloh for health drinks. Therefore, the need for processing with other forms and methods to be more practical and easy to consume can even increase the family's economic income. One of them is the use of turmeric into instant powder drinks with high economic value. The method used was socialization and counseling on the use of Turmeric, a Turmeric Processing Demo into Instant Powder Drinks and evaluation of activities. The results showed that Pakraman Pau villagers could increase their knowledge, understanding, and skills about using turmeric as an instant powder drink to maintain family health and could be a business opportunity for PKK mothers to help improve the family's economy
\end{abstract}

Keywords: Processing turmeric, instant powder

\section{Pendahuluan}

Indonesia memiliki keanekaragaman hayati lebih kurang 30.000 jenis tanaman, di mana 2.500 jenis di antaranya merupakan tanaman obat. Indonesia sebagai negara agraris juga memiliki hutan dan lahan pertanian yang luas serta menyimpan kekayaan alam yang besar. Berdasarkan hal itu, Indonesia mewariskan budaya pengobatan tradisional yang telah dikenal sejak dulu dan dilestarikan secara turun-temurun.

Bali merupakan pulau di Indonesia yang memiliki budaya pengobatan tradisional yang dikenal dengan nama usadha. Usadha merupakan ilmu pengobatan 
Jurnal Sewaka Bhakti

Lembaga Penelitian dan Pengabdian Kepada Masyarakat

Universitas Hindu Indonesia Denpasar

Volume 2, Nomor 1 April 2019

ISSN: 2654-2935 (Online)

https://ejournal.unhi.ac.id/index.php/sewakabhakti

pp. 73-81

tradisional Bali yang belum banyak digarap secara ilmiah, baik untuk kepentingan pengobatan secara lokal maupun global. Usada: berasal dari kata "ausadhi" (sansekerta) yang berarti tumbuhan yang berkhasiat obat. Usada merupakan suatu pengetahuan pengobatan yang disusun berdasarkan suatu acuan tertentu digabungkan dengan pengalaman praktek pengobatan di Bali yang telah ada sejak ratusan tahun yang lalu (Nala, 1991).

Adanya krisis ekonomi yang berlarut-larut saat ini menyebabkan pola hidup termasuk kebiasaan makan, menimbulkan banyak penyakit dan membuat kesehatan menjadi barang yang mahal. Mahalnya harga obat-obatan modern menyebabkan tingkat kesehatan masyarakat mengalami penurunan yang pada gilirannya akan mempengaruhi aspek kesejahteraan masyarakat umum dan akan berdampak negatif pada ketahanan dan kinerja bangsa.

Kurangnya daya beli masyarakat dan melambungnya harga obat-obatan modern memaksa masyarakat dan pemerintah mencari upaya mengatasi keadaan yang memprihatinkan ini dengan cara kembali ke alam atau back to nature seperti negara-negara maju yang secara luas telah menggunakan obat-obatan modern akhir-akhir ini menunjukkan indikasi lebih menyukai obat dari bahan alami dari pada obat-obatan sintetik. Salah satu faktor penyebabnya adalah pemanfaatan obatobat dari bahan alami relatif lebih aman dari pada pemakaian obat sintetis. Sampai saat ini potensi keanekaragaman tumbuhan liar di pedesaan dan perkampungan masyarakat yang bermanfaat obat-obatan masih banyak diabaikan dan belum dimanfaatkan serta belum dikembangkan untuk bahan obat-obatan dan bahkan berpotensi menjadi komoditi ekonomi. Hal ini terjadi antara lain karena pengetahuan dan teknologi yang rendah yang dimiliki masyarakat.

Desa Pekraman Pau merupakan salah satu desa yang berada di Kecamatan Banjarangkan Kabupaten Klungkung Provinsi Bali. Sebagai salah satu desa yang sedang berkembang di Klungkung yang kaya akan tanaman herbal. Tanaman herbal banyak ditanam di lahan pertanian maupun di pekarangan rumah warga. Tanaman herbal (yang dikenal dengan sebutan TOGA) tersebut salah satunya adalah kunyit. 
Jurnal Sewaka Bhakti

Lembaga Penelitian dan Pengabdian Kepada Masyarakat

Universitas Hindu Indonesia Denpasar

Volume 2, Nomor 1 April 2019

ISSN: 2654-2935 (Online)

https://ejournal.unhi.ac.id/index.php/sewakabhakti

pp. $73-81$

Pemanfaatan kunyit Belum diolah secara optimal, khususnya dalam bidang peningkatan kesehatan maupun nilai tambah dalam membantu meningkatkan perekonomian keluarga. Dengan demikian upaya pemberian pelatihan untuk memberikan bekal keterampilan kepada ibu rumah tangga warga desa Pekraman Pau sangat diperlukan untuk menambah pendapatan ekonomi rumah tangganya. Mayoritas masyarakat desa pekraman Pau mata pencahariannya adalah sebagai petani. Sehinggga yang dapat dihasilkan hanya beras saja tanpa dimanfaatkan sebagai olahan lain. Hal itu yang dapat menjadikan tidak ada perkembangan dalam meningkatkan perekonomian masyarakat.

Kunyit termasuk salah satu tanaman suku temu-temuan (Zingiberaceae) yang banyak ditanam di pekarangan, kebun dan di sekitar hutan jati. Kunyit dikenal sebagai penyedap, penetral bau anyir pada masakan dan juga sering dimanfaatkan sebagai ramuan obat tradisional untuk menyembuhkan berbagai penyakit. Saat ini kunyit sudah dimanfaatkan secara luas oleh industri makanan, minuman, obatobatan, kosmetik dan tekstil (Winarto, 2003). Kunyit merupakan tanaman suku temu-temuan dengan nama latin Curcuma longa linn atau Curcuma domestica Val. Senyawa utama yang terkandung dalam rimpang kunyit adalah senyawa kurkuminoid. Senyawa kurkuminoid ini yang memberikan warna kuning pada kunyit. Kurkuminoid ini menjadi pusat perhatian para peneliti yang mempelajari keamanan, sifat antioksidan, antiinflamasi, efek pencegah kanker, ditambah kemampuannya menurunkan resiko serangan jantung (Asghari G.A. Mostajeran and M. Shebli,2009)

Penggunaan kunyit secara umum biasanya dalam bentuk yang berbeda yaitu: bumbu, gelendongan, belahan, irisan, dan bubuk atau tepung. Warga masyarakat desa pekraman Pau hanya memanfaatkan kunyit untuk bumbu dapur dan digunakan sebagai loloh untuk menjaga kesehatan. Sedangkan minuman tradisional loloh dibuat hanya dengan merebus kunyit ditambah beberapa bahan seperti gula, asem dan air sehingga jangka waktu simpan tidak lebih dari 4 hari sehingga perlu pengolahan dengan bentuk dan metode yang lain untuk lebih praktis 
dan mudah dikonsumsi bahkan dapat menambah pendapatan ekonomi keluarga. Salah satunya adalah pemanfaatan kunyit menjadi minuman serbuk instan yang bernilai ekonomi tinggi. Selain itu dengan bentuk serbuk instan akan sangat berpotensi untuk mendatangkan keuntungan finasial yang besar, sehingga mampu meningkatkan pendapatan ekonomi keluarga. Jika warga memiliki wawasan dan jiwa wirausaha, maka produksi minuman serbuk herbal instan kunyit dapat menjadi alternatif usaha yang memiliki prospek untuk meningkatkan penghasilan keluarga dan membuka lapangan kerja. Produk tersebut dapat dijual di warung makanan, toko jamu, apotek atau toko obat, serta dapat didistribusikan ke luar desa. Pelatihan pemanfaatan Kunyit menjadi minuman serbuk Instan (siap saji) memberikan dampak postif sehingga warga Desa Pekraman Pau tidak hanya mengandalkan mata pencahariannya sebagai petani tetapi melatih untuk meningkatkan derajat pelatihan jamu kunyit menjadi instan yang siap saji yang tidak hanya dimanfaatkan untuk kewirausahaan tetapi untuk mengatasi masalah kesehatan di Desa Pekraman Pau.

\section{Metode Pelaksanaan}

Dalam usaha meningkatkan derajat perekonomian dan kesehatan masyarakat desa pakraman Pau maka dilaksanakan kegiatan dengan metode yang digunakan adalah metode partisipasi aktif melalui proses pendampingan dan pelatihan pembuatan minuman kesehatan berbasis herbal menggunakan kunyit untuk membekali keterampilan para ibu rumah tangga yang diawali dengan sosialisasi dan penyuluhan mengenai pemanfaatan Kunyit, Demo Pengolahan Kunyit Menjadi Minuman Serbuk Instan dan evaluasi kegiatan. Pelatihan diikuti oleh Kader Posyandu, Ibu PKK, istri Perangkat Desa, Guru TK Giri Putri, dan beberapa ibu rumah tangga di lingkungan Desa Pakraman Pau. Gambar metode pelaksanaan kegiatan dapat dilihat pada Gambar 1. 


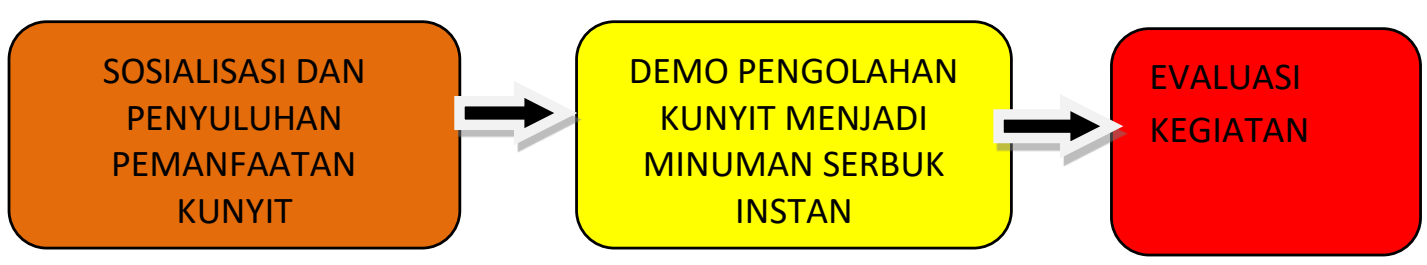

Gambar 2.1 Metode Pelaksanaan

\section{Hasil Dan Pembahasan}

\section{a. Sosialisasi dan Penyuluhan Pemanfatan Kunyit}

Kegiatan sosialisasi dan penyuluhan yang telah dilakukan diawali dengan pemanfatan TOGA (Tanaman Obat Keluarga) yang dibagi menjadi empat yaitu: (1) pengenalan berbagai spesies Tanaman obat keluarga (TOGA) kepada para peserta baik berupa ciri dan kegunaan; (2) teknik budidaya berbagai spesies tumbuhan obat, mulai berupa pohon sampai tumbuhan bawah atau herba; (3) teknik pasca panen tumbuhan obat, berupa pemanenan, pencucian, pengeringan dan penyimpanan; dan (4) teknik pembuatan produk obat tradisional, berupa instant, bubuk dan teh. Salah satu tanaman yang dapat dimanfaatkan adalah kunyit.

Kunyit termasuk salah satu tanaman suku temu-temuan (Zingiberaceae) yang banyak ditanam di pekarangan, kebun dan di sekitar hutan jati. Kunyit dikenal sebagai penyedap, penetral bau anyir pada masakan dan juga sering dimanfaatkan sebagai ramuan obat tradisional untuk menyembuhkan berbagai penyakit. Saat ini kunyit sudah dimanfaatkan secara luas oleh industri makanan, minuman, obatobatan, kosmetik dan tekstil.

Berbicara mengenai ramuan herbal yang popular di kalangan masyarakat Bali sangatlah bervariasi dan beragam. Pada umumnya ramuan herbal menggunakan tumbuhan yang berkhasiat obat. Bagian-bagian yang dimanfaatkan dari tumbuhan untuk pengobatan umumnya pada daun, akar, buah, batang, kulit kayu, hingga bagian yang menjalar. Pemanfaatan tanaman obat atau bahan obat alam pada umumnya sebenarnya bukanlah merupakan hal yang baru. 
Jurnal Sewaka Bhakti

Lembaga Penelitian dan Pengabdian Kepada Masyarakat

Universitas Hindu Indonesia Denpasar

Volume 2, Nomor 1 April 2019

ISSN: 2654-2935 (Online)

https://ejournal.unhi.ac.id/index.php/sewakabhakti

pp. $73-81$

Kenyataan menunjukkan bahwa dengan bantuan obat-obatan asal bahan alam tersebut, masyarakat dapat mengatasi masalah-masalah kesehatan yang dihadapinya. Hal ini menunjukkan bahwa obat yang berasal dari sumber bahan alam khususnya tanaman telah memperlihatkan peranannya dalam penyelenggaraan upaya-upaya kesehatan masyarakat. Gambar 3.1 Kegiatan sosialisasi dan penyuluhan pemanfaatan kunyit.

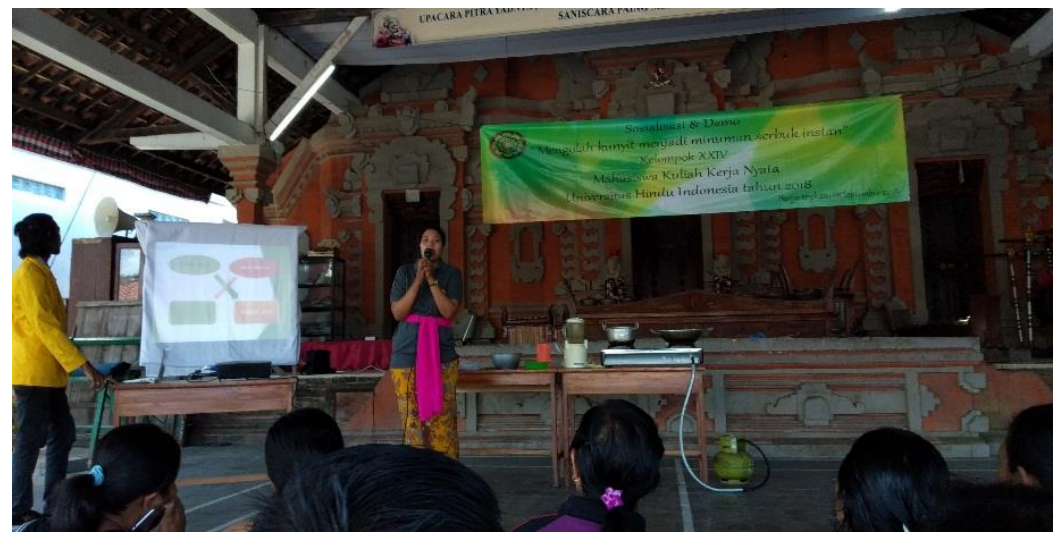

Gambar 3.1 Kegiatan sosialisasi dan penyuluhan pemanfaatan kunyit

Kegiatan sosialisasi atau pengarahan kepada peserta yang terdiri dari Kader Posyandu, Ibu PKK, istri Perangkat Desa, Guru TK Giri Putri, dan beberapa ibu rumah tangga di lingkungan Desa Pakraman Pau yang dilaksanakan bulan September 2018. Pada kegiatan tersebut telah disampaikan bagaimana pemanfaatan kunyit selain sebagai bumbu dapur juga dapat dijadikan minuman serbuk instan yang cepat saji, tahan lama dan lebih praktis sehingga dapat digunakan sebagai peluang wirausaha. Kegiatan sosialisasi dibantu dengan mahasiswa yang sedang melaksanakan KKN didesa Pekraman Pau Kecamatan Banjarangkan Klungkung. Kegiatan sosialisasi dapat

Selama kegiatan sosialisasi dan penyuluhan berlangsung para peserta pelatihan mengikuti kegiatan pelatihan dengan sabar, telaten, dan ceria. Kegiatan pelaksanaan penelitian juga melibatkan para mahasiswa Universitas Hindu Indonesia yang sedang melaksanakan kegiatan KKN. 
Jurnal Sewaka Bhakti Lembaga Penelitian dan Pengabdian Kepada Masyarakat Universitas Hindu Indonesia Denpasar Volume 2, Nomor 1 April 2019 ISSN: 2654-2935 (Online) https://ejournal.unhi.ac.id/index.php/sewakabhakti pp. $73-81$

\section{b. Demo Pengolahan Kunyit Menjadi Minuman Serbuk Instan}

Sebelum dilakukan demo pengolahan kunyit perlu disiapkan alat dan bahan yang digunakan untuk mengolah kunyit menjadi instan yaitu :

Alat-alat yang digunakan :

1. Wajan stain less

2. Kompor

3. Sendok kayu

4. Saringan

5. Parutan

6. Baskom

7. Blender

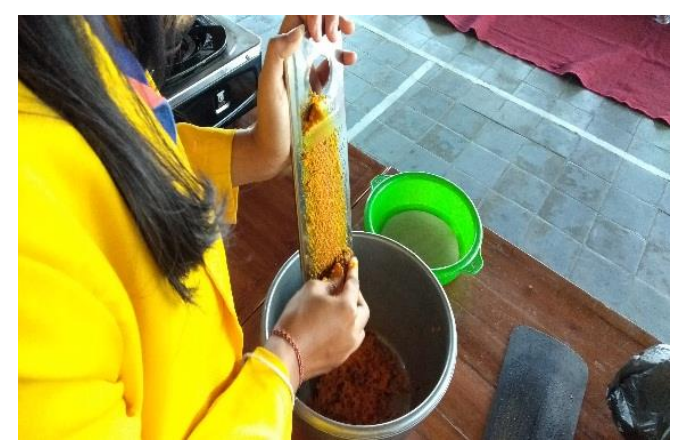

\section{Proses Pemarutan Kunyit}

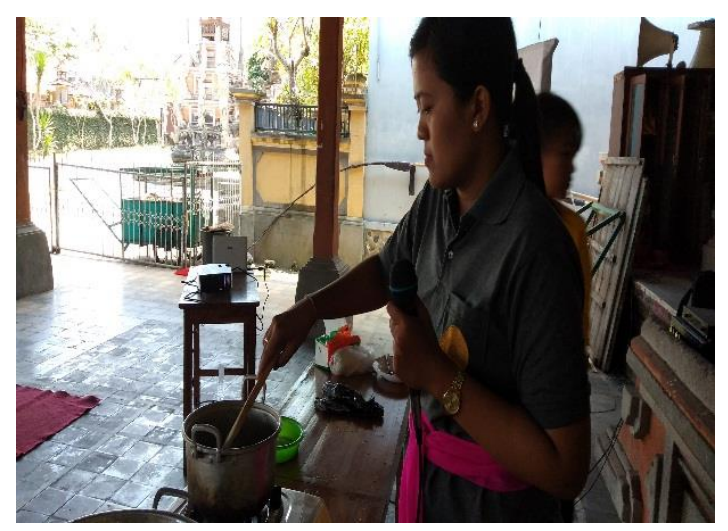

3. Proses perebusan air perasan kunyit rebusan kunyit wajan
Bahan-bahan yang digunakan :

1. 1 kg kunyit,

2. $1 \mathrm{~kg}$ gula pasir

3. 3 lembar daun pandan

4. Kain kasa

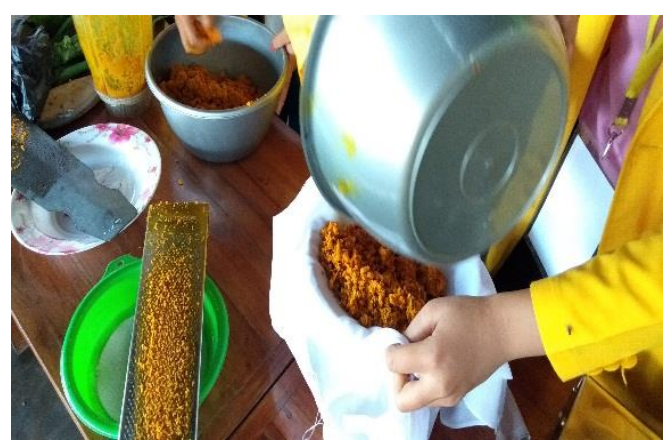

2. Proses pemerasan hasil parutan kunyit untuk Mengambil air perasannya

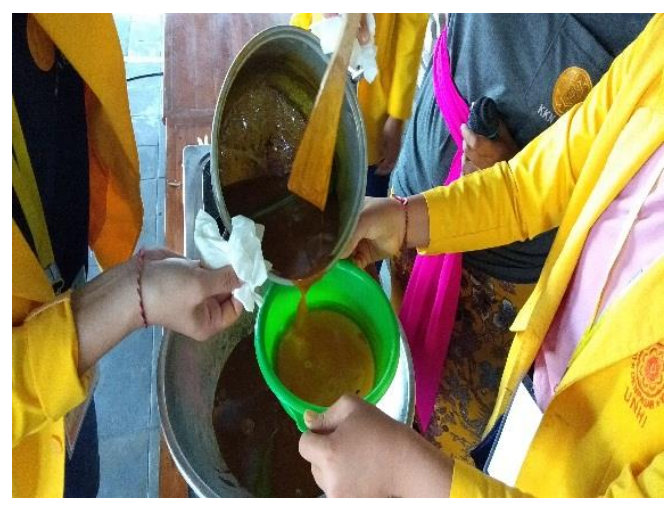

4. Proses penyaringan

ke dan penambahan Gula pasir 


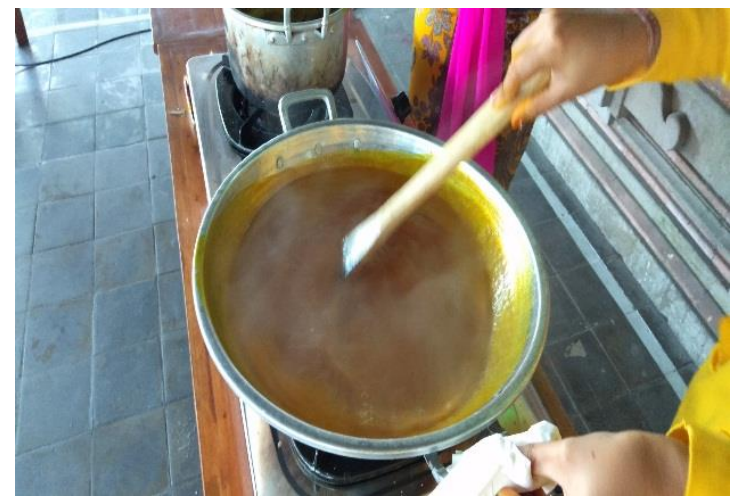

5. Proses kristalisasi kunyit menjadi instan kunyit diaduk selama 1 jam

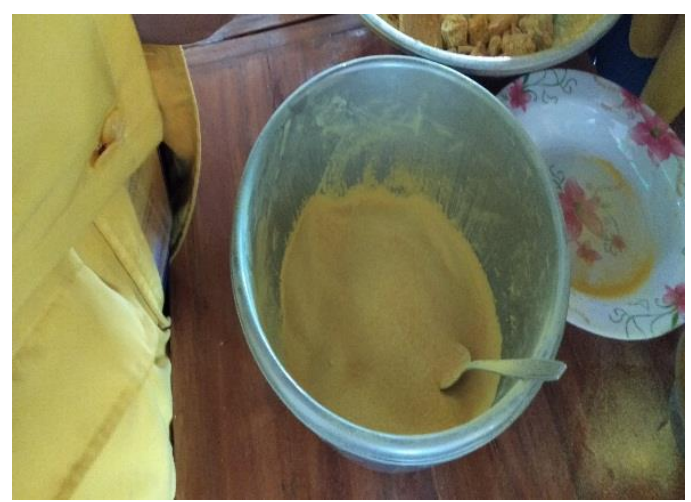

6. Hasil minuman serbuk instan

Setelah dilakukan pelatihan pembuatan minuman instan kunyit herbal, para ibu-ibu Kader Posyandu, Ibu PKK, istri Perangkat Desa, Guru TK Giri Putri, dan beberapa ibu rumah tangga di lingkungan Desa Pakraman Pau mampu membuat minuman herbal yang berupa instan (bentuk serbuk siap saji) dari bahan-bahan dasar kunyit untuk meningkatkan derajat kesehatan dan ekopnomi warga Pakraman Pau.

\section{c. Evaluasi Kegiatan}

Setelah dilakukan pelatihan dan pendampingan pembuatan atau pengolahan kunyit menjadi bubuk instan, maka untuk selanjutnya warga desa Pakraman Pau sudah mempraktekkan apa yang telah dilatih, guna mereka gunakan di dalam kelangan sendiri maupun mereka distribusikan keluar desa.

Evaluasi dimaksudkan untuk memberikan penyempurnaan terhadap program yang dilaksanakan apakah sudah sesuai dengan yang semestinya. Di dalam evaluasi tersebut terjadi komunikasi dua arah, apakah ada kendala di dalam melaksanakan sendiri kegiatan tersebut maupun hal-hal lain yang berkaitan dengan pembuatan instan. 
Jurnal Sewaka Bhakti

Lembaga Penelitian dan Pengabdian Kepada Masyarakat

Universitas Hindu Indonesia Denpasar

Volume 2, Nomor 1 April 2019

ISSN: 2654-2935 (Online)

https://ejournal.unhi.ac.id/index.php/sewakabhakti

pp. 73-81

\section{Simpulan Dan Saran}

\subsection{Simpulan}

Setelah dilaksanakan pengabdian masyarakat dengan penyuluhan dan pelatihan pengolahan kunyit maka warga desa Pekraman Pau sudah dapat menambah pengetahuan, pemahaman, dan keterampilan tentang pemanfaatan kunyit menjadi minuman serbuk instan untuk menjaga kesehatan keluarga. Selain itu, dengan adanya pelatihan pengolahan kunyit dapat menjadi peluang bisnis bagi ibu-ibu PKK sehingga dapat membantu meningkatkan perekonomian keluarga.

\subsection{Saran}

1. Perlu adanya pelatihan yang berkelanjutan untuk pengolahan serbuk instan tidak hanya dari kunyit tetapi juga dari tanaman obat lainnya

2. Perlu adanya pelatihan pengemasan minuman serbuk instan yang memiliki kualitas dan nilai jual tinggi

\section{Ucapan Terimakasih}

Ucapan terimakasih disampaikan kepada Rektor Universitas Hindu Indonesia, Dekan Fakultas Kesehatan, dan LPPM Universitas Hindu Indonesia Denpasar yang telah memfasilitasi sehingga kegiatan berjalan dengan baik dan dapat memenuhi target luaran serta ucapan terimakasih kami sampaikan kepada prajuru dan warga masyarakat Desa Pekraman Pau yang ikut berperan serta dalam mensukseskan kegiatan pengabdian masyarakat ini.

\section{Daftar Pustaka}

Asghari, G.A., Mostajeran, and M. Shebli. 2009. Curcuminoid and Essential Oil Components of Turmeric at Different Stages of Growth Cultivated in School of Pharmacy and Pharmaceutical Sciences. Isfahan University of Medical Sciences. Isfahan. Iran

Nala, Ngurah. 1991. Usada Bali. Denpasar: PT. Upada Sastra.

Winarto, W.P., 2003, Memanfaatkan Bumbu Dapur untuk Mengatasi Aneka Penyakit 1st ed. Mulyono, ed., Jakarta, AgroMedia Pustaka. 